\title{
THE GRIMM LEGACY IN PORTUGUESE CHILDREN'S LITERATURE: THE CASE OF LITTLE RED RIDING HOOD
}

\author{
Sara REIS DA SILVA \\ Institute of Education - University of Minho \\ sara_silva@ie.uminho.pt
}

merging as one of the best well-known tales of tradition, Little Red Riding Hood went from
an indefinable place of origin until the present day. As some researchers point out, the
predecessors of the famous text of Charles Perrault (1628-1703), were Greek narratives told by Pausanias (II century BC), Callimachus (III century BC) and Liberal Antonino (II or III century BC), as well as a short medieval text written by Egbert of Liege (Fecunda Ratis). The above-mentioned French author wrote and published it for the first time in the seventeenth century (1697), in the collection entitled Contes de Ma Mere L'Oye. But it was only in the nineteenth century that, with the signing of Jacob and Wilhelm Grimm, and Kinder-und Hausmärchen (1812), the more widespread matrix of this tale embedded by an oral tradition appeared, came to solidify the collective referent (Colomer, 1996) and, more often, has served as fertile ground for numerous translations, interpretations, adaptations and versions, which have, in most cases, the child or young people as preferred recipients.

This text, originated in the oral tradition, brings together some of the elements of other works that share the same literary substract. Teresa Colomer states that

per exemple, el diàleg enumeratiu del llop i la nena sobre les parts del cos coincideix amb un passatge dels Edda. Allà, l'heroi Thor s'ha vestit de dona per poder vèncer el gegant Thrym. El gegant se soprèn de la seva aparença I estableix un diàleg amb Loki, la dona de Thor, tot repassant les diferents parts del cos. També el motiu dels herois que reapareixen del ventre dels monstres que els han devorat pot trobar-se a la Teogonia d' Hesiode, al mite grec de Cronos que devora els seus fills o en el passatge bíblic de Jonàs i la balena. Per altra part, s' ha assenyalat que a la Fecunda ratis, d'Egbert de Liexa apareix la descripción d'una nena vestida de vermell i acompanyada de llops (Colomer, 2000: 56-57).

Along with these traditional elements, the same researcher adds the references to some similarities between Little Red Riding Hood and other folktales:

De Les set cabretes i el llop prové la mort del llop amb la panxa plena de pedres i d' Els tres porquets ve l'episodi del segon llop que és vençut per l'àvia i la nena, tot fent-lo caure des de la teulada a una pastera plena d'aigua (Colomer, 2000: 57). 
Thus Little Red Riding Hood seems to distinguish itself as an inescapable narrative of collective literary experiences, as well as a space of childhood stored in the personal memory of many adults, as it is evident in the plurality of direct and indirect references to this text across Western literature and among different publics (Beckett, 2002). The numerous versions of this text, "from the Perrault's spoiled version" to "Grimm's sensible" one, and finally, to the modern "protective" versions of the twentieth century", in the words of Zohar Shavit (2003: 27), along with the possibilities of recognizing different social perceptions of childhood that they allow, as mentioned by this researcher, evidence, in fact, the resistance to time erosion of literary subjects.

The phenomenon of disclosure inherent to the short story in question proves that, indeed, intertextuality appears as "one of the major principles of the constitution of the literary space" (Samoyault, 2001: 111) since, in its successive versions, it gathers several processes of reproduction or of reworking models and referents, and thus constructing a vivid literary universe, constantly in expansion, very innovative, creative and open to an endless game of crossed elements where the only rule is some epochal constraints.

In Portugal, one easily concludes about the high number of editions of texts attributed to Perrault and the Grimm brothers, who, since the second half of the nineteenth century, had a remarkable disclosure. Fit to this picture are, for example, Maria Amália Vaz de Carvalho and Gonçalves Crespo's collection Contos para Os Nossos Filhos (1882), a selection of twenty-five thousand, nineteen of Grimm, the two books in the collection Contos de Grimm (1883), which were collected by Salomão Saragga and are shown as the inaugural grimm portuguese publication, and also the translations of Henrique Marques Júnior, for "Biblioteca das Crianças" (1898-1910), a collection composed by thirteen volumes, entitled Contos de Fadas (1898/1905), which includes the text "O Chapelinho Encarnado".

From this perspective, the portuguese reception of this famous short story, as Maria Teresa Cortez explains, in the nineteenth century and even in the first decade of the twentieth century, was sporadic with an occasional presence in newspapers/journals dedicated to children. Such cases include a child play written by Hilda Dawdson and published in Serões (No. 18, Dec. 1906) and also the anonymous version "Capuz Vermelho", included in the section "Para as Crianças" in the newspaper named A Crónica.

Pierre Erny also points out a portuguese tale, which appeared in the "Revue Hispanique, 14, 1906, p. 189 et seq." (Erny, 2003: 52-53), and from which some models of the classical narrative in question became evident. In this context, the text "O Chapelinho Encarnado", included by J. Leite de Vasconcelos in Contos Populares Portugueses (Cortez, 2001: 416-417) should be noticed.

In fact, with a very different narrative grammar (even from the point of view of literary quality) and with distinct graphic settings, in the Portuguese literary universe has prevailed, with higher recurrence, the rewritings of Little Red Riding Hood according to the german reassuring paradigm, leaving to fall the ambiguity, the tragic conclusion and intentionality and / or morality of Perrault's 
text, which, in effect, situates this release matrix in the category of "cautionary" tales, as it is underlined by Teresa Colomer (2000), based on the classification advanced by P. Delarue (1951).

Regarding children's portuguese literature, as in most of the various foreign texts (narrative or filmic, for example), "Little Red Riding Hood is generally an unmistakable intertextual referent for even the youngest reader" (Beckett, 2002: 1), as maintained and extensively discusses Sandra L. Beckett both Recycling Red Riding Hood (2001) as Red Riding Hoodfor All Ages. The Fairy-Tale Icon in Cross-Cultural Contexts (2008).

The following texts will be subjected to a brief analysis, and some of them accompanied by different generations of young readers, prove the referred theoretical/creative rehearsed.

In the version included in Contos para a Infância (1877), by Guerra Junqueiro (1850-1923), a text titled as "O Chapelinho Encarnado", are projected some of the ideological axes that support the educational or didactic point of view preconized by the author on the literature to be received by the children are projected. Reread, in this regard, the preface of this book ("Duas palavras" ["Two Words"]), as well as, for example, the recurrence of discursive strategies such as diminutive forms in "rapariguinha", "avòzinha" [sic] and "pequenita" and the complimentary nature expressions (originated, for example, by the adjectives) as "muito bonita, cheia de bondade, a quem a mãe e a avó adoravam extremosamente. A santa avòzinha [sic]" (Junqueiro, 1978: 193), which mark the first paragraphs of the story rewritten by the author of Pátria. The answer of "Chapelinho Encarnado" to the request and the warnings of the mother suggest an obedience that is intended to be copied by the child reader: "Sim, mamã, respondeu ela, hei-de fazer tudo como deseja" (Junqueiro, 1978: 194).

In 1923, Maria Paula Azevedo (1881-1951) opens the collection Theatro para Creanças with the dramatic text "A Menina do Capuchinho Vermelho". If action, space-time configuration, or, even, the design of figures as the mother are intrinsically similar to the German model, the way the young protagonist sees the wolf appears somewhat different, because the girl innocently confuses it with a dog, which ultimately ends in laughter. In addition, in the conclusion of this dramatic text, we can see a discordant note regarding to grimm's tradition, since the intervention of the Hunter only motivates the rescue of Little Red Riding Hood, is rescue and doesn't have the usual untouched heroic character.

The short narrative "O Capuchinho Vermelho: Novela Infantil Contada às Crianças" (1967), by Leyguarda Ferreira (1897-?), consists of seven chapters which titles (I- A happy family; II- Disobedience; III- The wolf appears; IV- The wolf had no lunch; V- The cleverness of the grandmother; VI- A view of my friend wolf; VII- Once upon a time there was a wolf) show the crucial role of the wolf in the nuclear conflict of the diegesis. The external structure, suggested by the mentioned chapters, actually corresponds to an enlargement of the original classic text. The tale begins with a reference to a happy family, consisting of a digger -this male presence, an element that clearly deviates from the matricial text should be noticed-, his wife and daughter, to whom a rich lady offered a luxurious fabric to make a hood. This work is also noteworthy for its strong educational intention, which shows the judgmental tone that the narrator imprints the various segments of the speech with. 
Also having its first edition in 1967, A Nau Catrineta e a Outra História do Capuchinho Vermelho, by Alice Gomes (1910-1983), brings together two dramatic texts for children. In this text, the narrative "História do Capuchinho Vermelho e do Lobo Feroz" is embedded in the core actantial in which Paul and Mother are represented, functioning as a means of transposition into the dream, a space where the main character, Little Red Riding Hood, comes off the book, talks to the boy who reads his history and where, somehow, there is the opportunity to question the time lines and the importance of this traditional text's original teachings.

Other contemporary texts as the play "Capuchinho Vermelho" (in Contar e Cardar) (2002), by Mário Castrim, O Gorro Vermelho (2002), by Ana Saldanha, O Capuchinho Vermelho (na versão que as crianças mais gostam!) (2003), by Richard Câmara, A História do Capuchinho Vermelho Contada a Crianças e Nem Por Isso, by Manuel António Pina (2005), O Capuchinho Cinzento (2005), by Matilde Rosa Araújo, A Menina do Capuchinho Vermelho no Século XXI (2007), by Luísa Ducla Soares, "Capuchinho Vermelho" by Alice Vieira (2007), "O Capuchinho e o Lobo" (in Trinta por uma Linha) by AntónioTorrado (2008), and also Le Petit Chaperon Rouge / Little Red Cap / Chapelinho Encarnado, J. and W. Grimm (2009) also evidenced the persistence of intertextual effects of the classic tale in question in recent Portuguese writers activity, attesting to the strength of oral tradition in literature, as its primary heritage.

Written by Mário Castrim (1920-2002), the play "Capuchinho Vermelho" (2002) is included in Contar e Cardar, a book published in 2002, which gathers five new texts explicitly assembled for the Centro Experimental de Teatro de Aveiro, which was also responsible for its publication. With a clearly restricted diffusion, this dramatic text incorporates some key elements of the classical narrative, particularly in terms of the characters (Little Red Riding Hood, mother, grandmother, wolf and hunter), the main moments of action and a few ideological and thematic lines (as the transgression, for example). Its originality stems primarily from changes in areas covered by the heroine, with the use of place names/locations in the city of Aveiro (an appearance justified by the context of enactment and publication of the text) as the Feira de Março, Avenida Dr. Lourenço Peixinho or IP5, for example, and parody, largely motivated by the subtle libertine behavior, each in their on way, of Little Red Riding Hood and Grandmother.

In the novel $O$ Gorro Vermelho (2002), and passing the classic tale through the filter of the updated epochal and in a singular speech marked by fine humor and an unusual skill in recreating a social microcosm, that the reader will easily recognize, Ana Saldanha (1959-) fictionalizes issues that are included in the agenda: the insecurity lived in the cities, pedophilia or seniors. In this short narrative, individualization soon acquires a special importance as the basis of the transformation process. For example, there is a character named Sophie that represents the traditional Little Red Riding Hood.

The visual narrative signed by Richard Câmara (1973-), entitled O Capuchinho Vermelho (na versão que [sic] as crianças mais gostam!) (2003), is, in fact, one of the most deviated versions from the original hipotexts, especially due to its pictorial component which corresponds to contemporary 


\section{Tropelías. Revista de Teoría de la Literatura y Literatura Comparada, 23 (2015) \\ The Grimm legacy in portuguese children's literatura: the case of Little Red Riding Hood}

comics models. Constructed from the sequential combination of different perspectives equitable representing the experiential trajectories of the characters (Little Red Riding Hood, Big Bad Wolf, Hunter and Grandma), this text actualizes the spaces and the impulses of the various characters, offering the reader the possibility to follow, the sticker vignettes, these figures live in a parallel dimension, on a journey from the forest or the jungle to the "hardest natural jungle": the city. With a subtle irony, Richard Câmara distinguishes his narrative by throwing some social criticism.

Moreover, this humorous and critical component, in a way, moralizing, does, in part, resemble the text matrix signed by Perrault. As Claude de la Genardière(2000) highlights, in the manuscript version of the text, Perrault left some notes addressed to adults who wish to read the story, assuming the idea of an adult mediation. Hence

La moralité du Petit Chaperon Rouge [...] joue d'un humour adressé précisément aux auditeurs des salons littéraires dans lesquels étaient testés les écrits, s'échangeaient les idées et les thèmes, naissaient des modes, s'elaboraient de nouveaux genres littéraires. Cette moralité fait passer le lecteur, avec addresse, de l'enfant du conte aux "jeunes enfants", jusqu'aux "jeunes filles" et aux "jeunes demoiselles", qui "font très mal d'écouter toutes sortes de gens".

Ainsi, le conte, par la médiation de l'enfant -la héroine du récit, mais aussi l'enfant à qui peut être adressé le conte-, s'addresse à chacun, fait lever en chaque lecteur ou auditeur adulte sa part de loup, et sa part d'enfant aux prises avec le loup. Et cela, grâce à la distance de l'humour qui vient atténuer, à la fin du récit, le tragique du finale donné par Perrault au Petit Chaperon Rouge (Genardière, 2000: 136).

The tragedy that overshadows the conclusion of Perrault's version prevails in História do Capuchinho Vermelho Contada a Crianças e Nem Por Isso (2005), a short story written by Manuel António Pina based on six oil paintings by Paula Rego.

Ideological e thematic lines such as pedophilia or death (associated with the ideas of fear and doubt, for example) run through this work (and others) by this author. The first mentioned topic, pedophilia, is also, in some extent, with the conditions of modern life (with its inhumanity, job requirements, insecurity, broken families or appearance's empire, for example), guides the disturbingly tragic diegetic construction of the story in question. Take, for instance, the concluding passage of this story:

A mãe voltou então do trabalho e deu como lobo a dormir na sala e as roupas de Capuchinho Vermelho espalhadas pelo chão. Em grande aflição, percebeu logo o que se tinha passado. Cheia de raiva, correu ao anexo do quintal, trouxe uma forquilha e espetou-a no lobo com toda a força, matando-o. Seguidamente, pegou numa grande faca e tirou-lhe cuidadosamente a pele.

"Assim como assim", disse a mãe, "sempre fico com uma estola...".

Nos dias seguintes, a toilette da mãe foi objecto de grande admiração entre as colegas do escritório: um vestido vermelho rubro que lhe ficava muito muito bem e uma belíssima pele de lobo ao pescoço (Pina, 2005: 14-16).

[The mother went back home from work and saw the wolf sleeping in the living room and Little Red Riding Hood's clothes on the floor. In great distress, she immediately realized what happened. Filled with rage, she ran to the yard, brought a fork and stabbed it in the wolf with all her strength, killing it. Then she took a large knife and carefully removed its skin.

"Just as well", said the mother, "I'll also get a stole...".

In the following days, the mother's toilette was the subject of much admiration among her colleagues in the office: a crimson red dress that suited her very very well and a beautiful wolf fur around her neck (Pina, 2005: 14-16)] 
The poetic prose of Matilde Rosa Araújo (1921-2010) in O Capuchinho Cinzento (2005), proposes, in our view, a deep reflection about the human condition and the transience of life, a semantic framework that may not be easily grasped by the reader which is present in the dedication "To all children, with great tenderness...". The dialogue with the classic text can be read from the outset or from the title itself, which establishes the difference, in terms of symbolic implications, by the replacement of red by gray, as well as by intratextual evocations of the history of "Little Red Riding Hood / girl who took a cake to grandmother / and found the big bad wolf!" (Araújo, 2005:12) which is now the history of the Old Grey Riding Hood. In addition, the apparently threatening presence of the wolf, in this text, regarding the diegetic level. Picking up some elements of classical narrative -like the figures of Little Red Riding Hood and the Wolf, and the topics of childhood and fear-Matilde Rosa Araújo metaphors the theme of aging and different fears that it encloses.

A Menina do Capuchinho Vermelho no Século XXI (2007), by Luísa Ducla Soares (1939), also carries out a recreation of the classic tale, based on two fundamental strategies: the recovery of coded elements -such as the visit to her grandmother, the offer of a cake or the reference to the forest and to the "bad wolf"-; and the introduction of contemporary aspects -such as television, a mother who works in a factory and does not have time to make cakes, a forest that had burned in the summer, a car or a very independent grandmother who uses mobile phone.

In A que Sabe esta História? (2007), Alice Vieira includes a short story about Little Red Riding Hood. This story deviates very much from the matricial text by Perrault and the Grimm brothers. The characters, for example, perhaps representing perhaps the most "deviant" aspect, although there is the maintenance of the "classic" nucleus, show some singularities that reflect their roots in a time and even a distinct historical and cultural context and away from the canonical narratives. The wolf, for example, far from wanting to violently "eat" Little Red Riding Hood, just wants the picnic the girl takes in her basket. The vivacity of the speech and the humour that sustains the reader's attention, and which, by the way, marks Alice Vieira's literary work, also should be noticed.

Also far from the text matrix is the tale by António Torrado, "O Capuchinho e o Lobo", included in the book Trinta Por Uma Linha (2008). Marked by an intense sense of humour, sustained by an important strategy, the ambiguity or equivocation, the story portrays an occasional meeting of a wolf and a "little hood", who, in fact, is not a girl, but a monk, only recognized as such in an advanced stage of diegesis. Predominant in this text are the dialogical structure, as well as the conversational tone and the very accessible language in which it is written.

Le Petit Chaperon Rouge / Little Red Cap / O Chapelinho Encarnado, (2009), by Eugénio Roda, with illustrations by the Iranian Hassan Amekan, is also marked with the use of an informal registration in some cases, almost familiar, and discursive strategies such as adjectives and repetitions, which are fundamental aspects, in certain cases, for the construction of the comicity and to some kind of dramatization erasing. The invitation to the read and reread of this text is left at the end by the use of the well-known formula of closure: "Victory, victory, tell this story again". 
These texts -by Mário Castrim, Ana Saldanha, Richard Câmara, Manuel António Pina, Matilde Rosa Araújo, Luísa Ducla Soares, Alice Vieira, António Torrado and Eugénio Roda- seem to testify to the fact that a noticeable release for some archetypes of the matrix of Little Red Riding Hood started with the postmodern aesthetic challenging the reader to look at renovated texts and to critically and creatively look to the presente world (Malarte-Feldman, 2003-2004).

This textual "liberation" has been extended, significantly, to visual language built around the figure and/or the story of Little Red Riding Hood. Understandably, this space is not suitable for a comparative analysis of trends in the visual/illustrative/pictorial field or a dialogic reading of the iconic recreation of the heroin in question signed by André Letria, Richard Câmara, Paula Rego, Madalena Matoso or Fátima Afonso, in portuguese texts, and Florence Langois, Carmen Segovia, Lisbeth Zwerger, Kevta Pacovska, Marc Taeger, Alessandro Sanna or David Roberts in foreign editions, for example. Nonetheless, it would be a relevant way of revealing what we have just reflected about.

In conclusion, we reaffirm that, as the target of interest of many creative writers and illustrators, and belonging to the collective literary memory, Little Red Riding Hood is one of the most widely "recycled" and read texts in formal and non formal contacts with literary reading.

\section{Bibliography}

AraúJo, Matilde (2005): O Capuchinho Cinzento. Prior Velho, Paulinas Editora (illustrations: André Letria).

Azevedo, Maria Paula (1923): Theatro para Creanças. Lisboa, Libanio da Silva (illustrations: Milly Possoz).

BeCKETt, Sandra L. (2002): Recycling Red Riding Hood. New York, Routledge.

— (2004): "Recycling Red Riding Hood in a Comic Mode", in www.sacbf.org.za/2004\%/20papers /sandra\%20beckett.rtf (last consultation, 03-10-05).

- (2008): Red Riding Hood for all ages. A fairy-tale in cross-cultural contexts. Detroit, Wayne State University Press.

CÂMARA, Richard (2003): O Capuchinho Vermelho (na versão que as crianças mais gostam!). Lisboa, Edições Polvo.

CASTRIM, Mário (2002): "Capuchinho Vermelho", in Contar e Cardar. Aveiro, CETA, 35-47.

Colomer, Teresa (1996): "Eterna Caperucita. La renovación del imaginario colectivo", CLIJ (Cuadernos de Literatura Infantil y Juvenil), 87 (October 1996), 7-19.

- (2000): "La formació i renovació de l'imaginari cultural: l'exemple de la Caputxeta Vermella", in LLUCH, Gemma (ed.), De la narrativa oral a la literatura per a infants. Invenció d'una tradició literária. Alzira, Ediciones Bromera, 55-93.

Cortez, Maria Teresa (2001): Os Contos de Grimm em Portugal. A recepção dos KinderundHausmarchen entre 1837 e 1910. Coimbra, MinervaCoimbra / Centro Interuniversitário de Estudos Germanísticos / Universidade de Aveiro. 
ERNY, Pierre (2003): Sur les Traces du Petit Chaperon Rouge. Paris, L’Harmattan.

FERREIRA, Leyguarda (1967): O Capuchinho Encarnado: novela Infantil contada às crianças. Lisboa, Romano Torres (illustrations: Amorim).

Flor RebanAL, Javier (1997): “Caperucita Roja cumple 300 años (...y todavía está como una jovencita)", Peonza (Revista de Literatura Infantil e Juvenil), 42-43 (December 1997), 11-18.

Gomes, Alice (1967): A Nau Catrineta e a Outra História do Capuchinho Vermelho. Lisboa, Portugália Editores, $2^{a}$ ed., 1972 (illustrations: Câmara Leme).

GonzÁlez Marín, Susana (2003): “¿Existía Caperucita Roja antes de Perrault?”, CLIJ (Cuadernos de Literatura Infantil y Juvenil), 158 (March 2003), 17-22.

JÚdICE, Nuno (2005): B. I. do Capuchinho Vermelho. Lisboa, Apenas, $2^{\mathrm{a}}$ ed.

JunQueIRo, Guerra (1978): “O Chapelinho Encarnado", in Contos para a Infância. Porto, Lello \& Irmão, 193-199 (illustrations: Laura Costa).

ORESTEIN, Catherine (2002): Little Red Riding Hood Uncloaked. Sex, Morality and the Evolution of a Fairy Tale. New York, Basic Books.

PERERA SANTANA, Ángeles (2002): “Caperucita Roja en la LIJ contemporánea”, CLIJ (Cuadernos de Literatura Infantil y Juvenil), 151 (July-August 2002), 15-22.

PERES, Ana Maria Clark (2006): "Velha história em roupa nova: revisitando Chapeuzinho Vermelho", in Mesquita, Armindo (coord.), Mitologia, tradição e inovação. (Re)leituras para uma nova literatura infantil. Vila Nova de Gaia, Gailivro, 213-221.

PINA, Manuel António (2005): A História do Capuchinho Vermelho contada a crianças e nem por isso. Porto, Público / Fundação de Serralves (illustrations: Paula Rego).

RodA, Eugénio (2009): Le Petit Chaperon Rouge / Little Red Cap / O Chapelinho Encarnado. Porto, Edições Eterogémeas (ilustrações: Hassan Amehkan).

SAlDANHA, Ana (2002): O Gorro Vermelho. Lisboa, Caminho.

Shavit, Zohar (2003): Poética da Literatura para Crianças. Lisboa, Caminho.

SiLVA, Francisco Vaz (2011): Capuchinho Vermelho Ontem e Hoje. Lisboa, Temas e Debates / Círculo de Leitores.

Silva, Sara Reis (2007): "O Capuchinho Vermelho revisitado: leituras de História do Capuchinho Vermelho Contada a Crianças e Nem por isso, de Manuel António Pina", in AzEVEdo, Fernando et alii (coord.), Imaginário, Identidades e Margens. Estudos em torno da Literatura InfantoJuvenil. Vila Nova de Gaia, Gailivro, 402-415.

SoARes, Luísa Ducla (2007): A Menina do Capuchinho Vermelho no Século XXI. Porto, Civilização (illustrations: Helena Simas).

VANDENDORPE, Christian (2000): “D'un conte à sa parodie: Le Petit Chaperon Rouge de Jacques Ferron”, in http://www.ruor.uottawa.ca/handle/10393/12815 (last consultation, 30-12-14).

VIEIRA, Alice (2007): "Capuchinho Vermelho", in A que sabe esta história? Cruz Quebrada, Oficina do Livro, 8-11 (illustrations: Carla Nazareth). 